\title{
Simulated green turtle grazing affects structure and productivity of seagrass pastures
}

\author{
Kathleen L. Moran, Karen A. Bjorndal* \\ Archie Carr Center for Sea Turtle Research and Department of Zoology, University of Florida, PO Box 118525, \\ Gainesville, Florida 32611, USA
}

\begin{abstract}
The seagrass Thalassia testudinum evolved under much greater grazing pressure than exists today because overexploitation by humans caused the severe decline of green turtles Chelonia mydas, the major seagrass herbivore in the Caribbean. Understanding the effects of grazing on the structure and function of seagrass ecosystems is critical to evaluating how ecosystem processes have changed since the major herbivore was essentially removed from modern Caribbean seagrass systems. We evaluated effects of grazing on the structure and productivity of $T$. testudinum pastures by simulating green turtle grazing in $3 \times 3 \mathrm{~m}$ plots for $16 \mathrm{mo}$ in the central Bahamas and comparing these clipped plots to adjacent control (unclipped) plots. Simulated grazing affected the physical structure of T. testudinum plots, resulting in a system with reduced structural complexity. Simulated grazing resulted in compensatory growth in T. testudinum. Clipped plots maintained levels of growth comparable to unclipped plots over the 16 mo clipping trial, and specific mass growth was significantly elevated in clipped plots, even without simulating the nutrient return from green turtle feces and urine. The green turtle grazing pattern of re-cropping T. testudinum plots is sustainable for long periodsat least 16 mo. We estimated a range of carrying capacities of T. testudinum for green turtles of 1567 to $3748 \mathrm{~kg}$ turtle $\mathrm{ha}^{-1}$. Our study provides a foundation for reconstruction models and restoration plans for Caribbean seagrass ecosystems.
\end{abstract}

KEY WORDS: Seagrass - Thalassia testudinum • Chelonia mydas Effects of grazing · Herbivory • Productivity $\cdot$ Compensatory growth

\section{INTRODUCTION}

Seagrasses are the foundation for some of the most productive ecosystems in the world, relative to other marine and terrestrial communities (Duarte \& Chiscano 1999). A great variety of species, ranging in size from small epibiotic amphipods to dugongs Dugong dugon, feeds, at least in part, on live seagrass tissues. McRoy \& Helfferich (1980) assembled a list of 154 species that feed on seagrasses, but if the compilation is limited to those species for which live seagrass blades compose $>10 \%$ of the diet, the number is cut by about half (Thayer et al. 1984). Earlier reviews that reported that only a small fraction of seagrass aboveground productivity passes through herbivores (Kikuchi 1980, Ogden 1980) have been contradicted by more recent reviews (Cebrián \& Duarte 1998, Valentine \& Heck
1999) indicating that herbivores can consume up to $100 \%$ of seagrass aboveground production. However, these and other studies concur that, today, seagrass herbivores usually consume relatively small amounts of aboveground production $(<30 \%)$, have a modest effect on leaf growth rates, usually do not substantially reduce aboveground biomass, often have little control over community structure and have been drastically reduced from historic levels (Valentine et al. 1997, Cebrián \& Duarte 1998, Cebrián et al. 1998, Valentine \& Heck 1999, Kirsch et al. 2002).

Seagrass herbivores exhibit a variety of foraging techniques, and their influences on the structure and productivity of seagrasses vary accordingly (Thayer et al. 1984). Dugongs create trenches through seagrass beds, uprooting and ingesting rhizomes along with leaf blades, and have a greater effect than green turtles 
Chelonia mydas that ingest entire blades without disturbing the belowground plant parts (Aragones \& Marsh 2000). In turn, these large herbivores have greater effects than smaller herbivores, such as parrotfish (Scaridae) that remove discrete bites from leaf blades and snails that scrape narrow strips along the blades.

Thalassia testudinum is a seagrass that forms extensive pastures in the Greater Caribbean, with long, strap-like blades and a dense belowground network of roots and horizontal rhizomes. This network serves as a support and storage system for a series of vertical short shoots, each bearing from 2 to 8 leaf blades that grow from a basal meristem (den Hartog 1970).

Green turtles in the Caribbean feed primarily on Thalassia testudinum (Bjorndal 1997) and exhibit a foraging pattern in which they do not graze randomly. They select young, actively growing tissue at the base of the leaves and allow the upper, older part of the leaves to float away (Audubon 1897, Bjorndal 1980). Once the older tissue has been cleared, green turtles can maintain grazing plots by re-cropping blades in those plots within a few centimeters of the substrate (Fig. 1). Where green turtle populations are more dense and/or the $T$. testudinum stands are less dense, grazing plots can merge so that entire $T$. testudinum beds are grazed, and green turtles may spend up to $9 \mathrm{~h}$ $\mathrm{d}^{-1}$ feeding in these sparse pastures (Williams 1988). Ogden et al. (1983) also observed very small cropped areas $\left(\sim 0.1 \mathrm{~m}^{2}\right)$ in $T$. testudinum beds that had been created by small green turtles and that were apparently not maintained as grazed plots. These grazing scars may be made by transient green turtles that have not established residency in the feeding area or by green turtles at low population densities.

A suite of responses of Thalassia testudinum to intensive grazing by green turtles was proposed by Thayer et al. (1984). Initially, blade growth would increase and blade tissue would have higher nitrogen and lower lignin content than ungrazed blades. Repeated cropping, however, would stress the plant; blade width, number of shoots per area and number of leaves per shoot would decrease, and blade production would decline within a year. Reduced blade production would result from depleted rhizome stores as soluble carbohydrates and protein were mobilized for leaf growth and from lowered input of nitrogen from detritus. Detritus would be reduced because the shorter, cropped blades would have a decreased capacity to trap and retain exogenous detritus and blade removal by the green turtles would reduce a primary source of detritus. Declining productivity and forage quality in the grazing plots would cause green turtles to abandon the plots and establish new ones elsewhere. These proposed responses in the structure and productivity of
T. testudinum beds to green turtle grazing have been addressed in few studies (Zieman et al. 1984, Williams 1988), and the extent to which the maintenance of grazing plots by green turtles is a sustainable foraging strategy is not known.

The decline of green turtles in the Caribbean as a result of over-exploitation by humans is well documented from archeological sites and historical records (Parsons 1962, Pandolfi et al. 2003) and is estimated to be as great as 93 to $97 \%$ (Jackson et al. 2001). Before this drastic decline, green turtles, numbering in the tens of millions, may have consumed much of the primary production of Thalassia testudinum (Bjorndal 1982, Jackson 1997, Bjorndal et al. 2000) and undoubtedly affected the structure, function and productivity of seagrass ecosystems in the Caribbean (Bjorndal 1980, Ogden 1980, Thayer et al. 1982, 1984, Hay 1984). The seagrass ecosystems that marine ecologists have studied over the last few decades in the Caribbean are characterized by largely detrital-based foodwebs and long blades with heavy loads of epibionts that trap detritus and shelter a diverse assemblage of organisms (Hemminga \& Duarte 2000). These characteristics may not represent the product of long-term selective pressures, but rather the release from grazing pressure following the decline of green turtle populations (Bjorndal 1980, Jackson 1997, Domning 2001). Restoration of

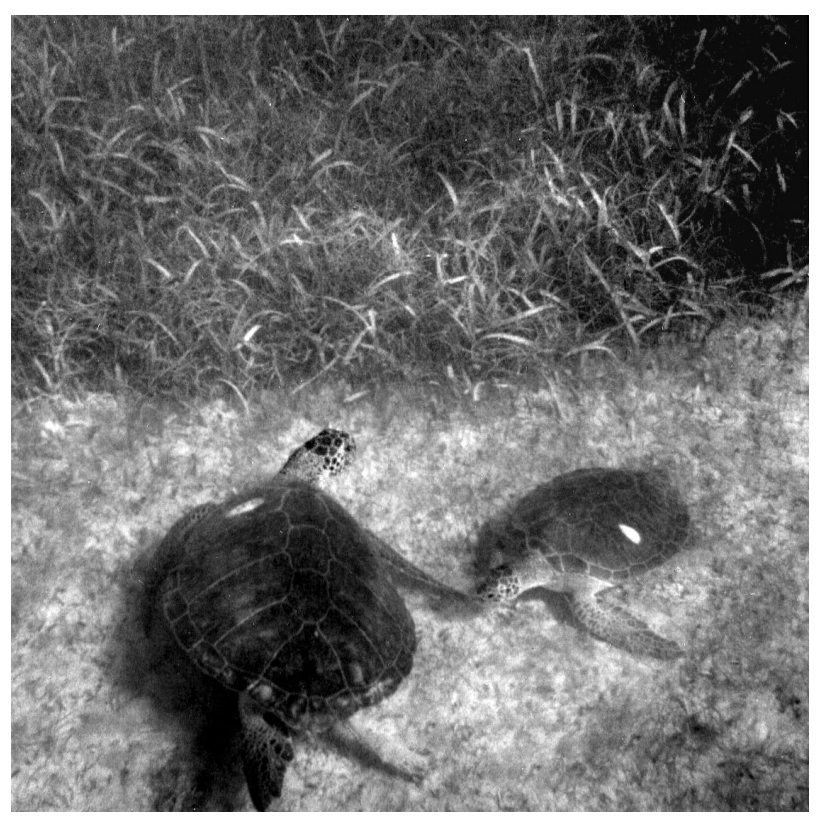

Fig. 1 Chelonia mydas. Green turtles in a grazing plot in a Thalassia testudinum pasture off the coast of Quintana Roo, Mexico. Note the sharp division between the grazed area in the foreground and the ungrazed area in the background. White spots on the turtles are 'living tags' (Balazs 1999). Photo by permission of Sheldon I. Aptekar 
marine ecosystems to past diversity and productivity requires knowledge of their past structure and function so that specific goals for recovery can be established and management plans developed (Jackson et al. 2001, Pitcher 2001). Estimates of carrying capacity (the capacity of the environment for supporting individuals) can be used as maximum estimates of green turtle population levels before exploitation by humans began and provide a historical perspective for evaluating the ecological roles of sea turtles (Jackson et al. 2001, Bjorndal \& Jackson 2003).

To evaluate the changes in structure, nutrient composition and productivity of Thalassia testudinum pastures grazed by green turtles and to compare them to the suite of responses proposed by Thayer et al. (1984), we simulated grazing by green turtles by repeatedly clipping plots of $T$. testudinum in the central Bahamas for 16 mo. We evaluated responses to simulated grazing by quantifying-in clipped and unclipped plots-plant structure, above- and belowground biomass, aboveground productivity, nutrient composition of blades and rhizomes and organic content of the sediment. We present these data here, except for the nutrient data that, due to the size of the study, are presented separately (K. L. Moran \& K. A. Bjorndal unpubl. data). We also evaluate the sustainability of re-cropping grazing plots and re-assess earlier estimates of carrying capacity of Caribbean $T$. testudinum pastures for green turtles.

\section{MATERIALS AND METHODS}

Study area and experimental plots. The study was conducted from July 1999 through December 2000 at the Caribbean Marine Research Center on Lee Stocking Island, Exuma Cays, Bahamas $\left(23.46^{\circ} \mathrm{N}, 76.06^{\circ} \mathrm{W}\right)$. The study site was a contiguous, monospecific stand of Thalassia testudinum at $3 \mathrm{~m}$ depth (mean low water level) located approximately $400 \mathrm{~m}$ southwest of Lee Stocking Island (Moran 2003). The site had a tidal range of approximately $1.5 \mathrm{~m}$, a very low current flow, oligotrophic waters and carbonate sediments. No green turtles Chelonia mydas were seen in the area during our study; there is a legal harvest of green turtles in the Bahamas. Herbivorous fishes (Sparisoma radians, Scarus taeniopterus, Scarus croicensis) were present at low levels, herbivorous invertebrates were rare and epibiont loads on $T$. testudinum blades were very light. The detrital layer was composed primarily of decomposing $T$. testudinum blades.

Thirty $3 \times 3 \mathrm{~m}$ plots were established in the seagrass bed in July 1999; 15 plots remained unclipped, and 15 plots were clipped to simulate grazing by green turtles. An additional 5 clipped plots were established in Feb- ruary 2000 to test for effects of season of clipping initiation (summer vs. winter) on seagrass response. Distances between nearest neighbor plots ranged from 4 to $50 \mathrm{~m}$; clipped and unclipped plots were alternated. Rhizomes around the edges of each clipped plot were severed to a depth of $\sim 35 \mathrm{~cm}$ with a flat-bladed shovel every 6 to $8 \mathrm{wk}$ to prevent nutrient translocation along rhizomes into the clipped plots from adjacent unclipped areas and to mimic a larger plot size. Corners of the outer $3 \times 3 \mathrm{~m}$ and the central $2 \times 2 \mathrm{~m}$ areas were marked with PVC pipe, and outer and inner areas were outlined with polypropylene string at sediment height.

The clipping regime was designed to mimic green turtle grazing. All Thalassia testudinum blades in each clipped plot were initially clipped with stainless steel scissors just above the blade/sheath junction $(\sim 2 \mathrm{~cm}$ above the sediment), simulating a green turtle grazing pattern (Bjorndal 1980). All blades in each clipped plot were re-clipped when mean blade length reached $5 \mathrm{~cm}$ above the blade/sheath junction, approximating the $5 \mathrm{~cm}$ bite size of a foraging green turtle (Ogden et al. 1983, Williams 1988). All clipped blades were collected in small-mesh bags. Clipping was maintained in the original 15 clipped plots from July 1999 through November 2000 and from February 2000 through December 2000 in the 5 clipped plots established in February. One of us (K. L. Moran) logged over $1700 \mathrm{~h}$ of SCUBA time conducting this clipping trial.

Sample and data collection. Salinity and maximum and minimum temperatures were measured weekly at $08: 30 \mathrm{~h}$ at 3 sites within the plots. Salinity (\%) of a water sample taken at blade canopy height was determined with a hand-held refractometer that was calibrated before each use. Temperatures $\left({ }^{\circ} \mathrm{C}\right)$ were read from maximum-minimum thermometers that were anchored to the sediment at blade canopy height and re-set each week.

The outer $0.5 \mathrm{~m}$ wide border $\left(5 \mathrm{~m}^{2}\right.$ area) of each clipped plot was treated as a buffer zone for any shading/sheltering effects due to adjacent unclipped seagrass. At each clipping, blades from the outer $0.5 \mathrm{~m}$ border were removed and discarded. All samples for analyses were collected from the remaining $2 \times 2 \mathrm{~m}$ area in the center of each plot. Aboveground biomass was measured in three $0.0625 \mathrm{~m}^{2}(25 \times 25 \mathrm{~cm})$ quadrats in each unclipped plot at $0,2,6,11$ and 16 mo. In clipped plots, aboveground biomass was the dry mass (DM) of all blades collected from the interior $4 \mathrm{~m}^{2}$ area of each plot at each clipping (range of 12 to $38 \mathrm{~d}$ intervals, depending on time to $5 \mathrm{~cm}$ mean blade length). Belowground biomass (short shoots, rhizomes, and roots) was collected from one $1140 \mathrm{~cm}^{3}(7.62 \mathrm{~cm}$ inner diameter, $25 \mathrm{~cm}$ depth) core in each plot. In this paper, we will refer to aboveground biomass as blades, and 
belowground biomass as rhizomes. Blade and rhizome samples were rinsed in salt water to remove sediment, dried to a constant weight at $60^{\circ} \mathrm{C}$ and weighed.

At 2 wk intervals, structural measurements were made in each unclipped and clipped plot. Blade length $( \pm 1.0 \mathrm{~mm})$ and width $( \pm 0.5 \mathrm{~mm})$ of 30 randomly selected blades were measured in each plot. Length was measured from the blade/sheath junction to the blade tip; width was measured at the widest part of the blade. Number of blades per shoot, shoot density (shoots $\mathrm{m}^{-2}$ ) and thickness of the detrital layer $(\mathrm{cm})$ were quantified in three $0.0625 \mathrm{~m}^{2}(25 \times 25 \mathrm{~cm})$ quadrats in each plot. Detrital layer thickness was measured by pressing a plastic ruler through the flocculent layer of detritus.

Productivity was measured as blade growth in length $\left(\mathrm{mm}\right.$ blade $\left.{ }^{-1} \mathrm{~d}^{-1}\right)$, area $\left(\mathrm{mm}^{2}\right.$ blade $\left.{ }^{-1} \mathrm{~d}^{-1}\right)$, absolute mass (g DM m ${ }^{-2} \mathrm{~d}^{-1}$ ) and specific mass (\% $\left.\mathrm{d}^{-1}\right)$. Linear growth $\left(\mathrm{mm} \mathrm{d}^{-1}\right)$ since the previous clipping was determined in clipped plots immediately before each clipping by measuring lengths above the blade/sheath junction of 30 randomly selected blades in the inner $4 \mathrm{~m}^{2}$ area of each plot. Linear growth of 30 random blades was measured in each unclipped plot using a staple technique (Zieman 1974). A staple was placed vertically in the blade just above the blade/ sheath junction, and the vertical movement of the staple was measured after $2 \mathrm{wk}$. Blades were selected randomly, rather than in specific age ranks. Because blade length growth was used to calculate blade area growth in clipped and unclipped plots and mass blade growth in unclipped plots, accuracy in estimating mean growth in each plot was more important than precision in estimating linear growth in a given blade age rank. Because blade width differed between clipped and unclipped plots, growth rates of blade area $\left(\mathrm{mm}^{2}\right.$ blade $\left.{ }^{-1} \mathrm{~d}^{-1}\right)$ were also calculated, using linear growth and average widths of blades during that time period. Growth in mass (g DM m${ }^{-2} \mathrm{~d}^{-1}$ ) of blades was quantified for each clipped plot by dividing the DM of the blades collected at each clipping $\left(4 \mathrm{~m}^{2}\right.$ area) by the number of days that had elapsed since the previous clipping. Mass growth of blades in each unclipped plot was calculated at $2 \mathrm{wk}$ intervals using the equation:

$$
(\mathrm{AG} \times \mathrm{MPA} \times \mathrm{BPS} \times \mathrm{SD}) / \text { days }
$$

where AG is blade area growth $\left(\mathrm{mm}^{2}\right.$ blade $\left.{ }^{-1} \mathrm{~d}^{-1}\right)$, MPA is the mass per area of blade $\left(\mathrm{g} \mathrm{mm}^{-2}\right)$, BPS is blades per shoot and SD is shoot density $\left(\right.$ shoots $\mathrm{m}^{-2}$ ). Specific mass growth is blade mass growth $\left(\mathrm{g} \mathrm{m}^{-2} \mathrm{~d}^{-1}\right)$ divided by blade biomass $\left(\mathrm{g} \mathrm{m}^{-2}\right)$ multiplied by 100 . To calculate specific mass growth, we used the blade mass growth value calculated for the interval $(\sim 2 \mathrm{wk}$ for unclipped plots; 12 to $38 \mathrm{~d}$ for clipped plots) prior to the measurement of blade biomass. Specific mass growth was only calculated for unclipped plots at the 5 sampling times when blade biomass was measured. Specific mass growth is equivalent to turnover and productivity:biomass ratios $(P: B)$ in other studies.

Data analyses. All parameters were analzyed using a 2 -factor repeated-measures ANOVA to compare the clipped and unclipped treatments over the 16 mo clipping experiment with time as the within-subject factor and treatment (clipped vs. unclipped plots) as the between-subject factor. If Mauchly's criterion indicated rejection of the compound symmetry assumption, adjusted probability values are presented. The 4 growth parameters were measured at different intervals for clipped plots and unclipped plots. All data are plotted in the figures, but repeated-measures ANOVA were conducted on the same number of intervals (see Table 1) by matching the closest sampling times.

We used Student's $t$-tests to test for homogeneity in structure parameters between clipped and unclipped plots at the beginning of the clipping trial. To evaluate the effect of season (summer or winter) when clipping was initiated, we controlled for an 11 mo clipping interval and, with Student's $t$-tests, compared unclipped plots with summer-initiated clipped plots in May 2000 and unclipped plots with winter-initiated clipped plots in December 2000.

Differences were considered significant at the $\alpha=$ 0.05 level. Bonferroni corrections were not applied to $\mathrm{p}$-values because of concerns that the probability of making a Type II error would become excessive (Perneger 1998). For those parameters measured in 3 quadrats in each plot at each sampling interval (blades per shoot, shoot density and detritus thickness in all plots and blade biomass in unclipped plots), the mean of the 3 quadrats was used as the plot value. All analyses were run in SPSS (Version 10.0) or S-PLUS (Version 6.1).

\section{RESULTS}

\section{Characteristics of the study site}

Temperature varied seasonally (Fig. 2a). Between July 1999 and December 2000, average weekly temperatures ranged from 23.4 to $31.8^{\circ} \mathrm{C}$ (mean $=27.8^{\circ} \mathrm{C}$, $\mathrm{SD}=2.5$ ). During the same period, weekly salinity measurements ranged from 34 to $41 \%$ o (mean $=38 \%$, $\mathrm{SD}=2$ ). Salinity showed no seasonal cycle, but salinity was reduced in October 1999 when Hurricane Floyd passed over the study area (Fig. 2a).

Our study site was typical of Thalassia testudinum pastures in the Greater Caribbean based on a comparison of our site (means of the 15 unclipped plots) with the 14 sites in the CARICOMP system (CARICOMP 
Table 1. Thalassia testudinum. Repeated-measures analyses of variance for differences in physical structure and blade growth variables with measurements taken over 16 mo for clipped and unclipped plots. Sample sizes are number of time intervals (time $\mathrm{n}$ ) and number of plots (plot $\mathrm{n}=$ unclipped plots, clipped plots); 1 clipped plot was not used as a result of hurricane damage. Significant values in bold

\begin{tabular}{|c|c|c|c|}
\hline & Source & $F$ & $\mathrm{p}$ \\
\hline \multicolumn{4}{|l|}{ Physical structure } \\
\hline Blade width & Time & 10.574 & $<0.001$ \\
\hline (time $\mathrm{n}=26$ ) & Time $\times$ treatment & 5.652 & $<0.001$ \\
\hline$($ plot $\mathrm{n}=15,14)$ & Treatment & 246.654 & $<0.001$ \\
\hline \multirow{3}{*}{$\begin{array}{l}\text { Blades per shoot } \\
\text { (time } n=26 \text { ) } \\
(\text { plot } n=15,14)\end{array}$} & Time & 80.914 & $<0.001$ \\
\hline & Time $\times$ treatment & 2.013 & 0.167 \\
\hline & Treatment & 1.202 & 0.283 \\
\hline \multirow{3}{*}{$\begin{array}{l}\text { Shoot density } \\
\text { (time } \mathrm{n}=26) \\
(\text { plot } \mathrm{n}=15,14)\end{array}$} & Time & 1.990 & 0.022 \\
\hline & Time $\times$ treatment & 1.722 & 0.057 \\
\hline & Treatment & 0.889 & 0.354 \\
\hline \multirow{3}{*}{$\begin{array}{l}\text { Detrital layer } \\
\text { (time } n=26) \\
(\text { plot } n=15,14)\end{array}$} & Time & 6.412 & 0.017 \\
\hline & Time $\times$ treatment & 3.728 & 0.064 \\
\hline & Treatment & 10.622 & 0.003 \\
\hline \multirow{3}{*}{$\begin{array}{l}\text { Rhizome biomass } \\
\text { (time } n=4) \\
(\text { plot } n=15,14)\end{array}$} & Time & 0.295 & 0.829 \\
\hline & Time $\times$ treatment & 0.715 & 0.546 \\
\hline & Treatment & 0.270 & 0.607 \\
\hline \multicolumn{4}{|l|}{ Blade growth } \\
\hline \multirow{3}{*}{$\begin{array}{l}\text { Linear growth } \\
\left(\mathrm{mm}^{-1} \text { blade } \mathrm{d}^{-1}\right) \\
(\text { time } \mathrm{n}=18) \\
(\text { plot } \mathrm{n}=15,14)\end{array}$} & Time & 94.45 & $<0.001$ \\
\hline & Time $\times$ treatment & 4.25 & 0.059 \\
\hline & Treatment & 143.95 & $<0.001$ \\
\hline \multirow{3}{*}{$\begin{array}{l}\text { Area growth } \\
\left(\mathrm{mm}^{2} \text { blade }{ }^{-1} \mathrm{~d}^{-1}\right) \\
(\text { time } \mathrm{n}=18) \\
(\text { plot } \mathrm{n}=15,14)\end{array}$} & Time & 103.34 & $<0.001$ \\
\hline & Time $\times$ treatment & 3.38 & 0.077 \\
\hline & Treatment & 8.00 & 0.009 \\
\hline \multirow{3}{*}{$\begin{array}{l}\text { Mass growth } \\
\left(\mathrm{g} \mathrm{m}^{-2} \mathrm{~d}^{-1}\right) \\
(\text { time } \mathrm{n}=18) \\
(\text { plot } \mathrm{n}=15,14)\end{array}$} & Time & 76.88 & $<0.001$ \\
\hline & Time $\times$ treatment & 4.42 & 0.045 \\
\hline & Treatment & 0.19 & 0.665 \\
\hline \multirow{3}{*}{$\begin{array}{l}\text { Specific mass } \\
\text { growth }\left(\% \mathrm{~d}^{-1}\right) \\
\text { (time } \mathrm{n}=5) \\
(\text { plot } \mathrm{n}=15,14)\end{array}$} & Time & 41.43 & $<0.001$ \\
\hline & Time $\times$ treatment & 27.45 & $<0.001$ \\
\hline & Treatment & $1,528.51$ & $<0.001$ \\
\hline
\end{tabular}

$1997 a, b)$. Eight of the parameters we measured were reported by CARICOMP. Mean monthly temperature, shoot density (shoots $\mathrm{m}^{-2}$ ) and blade biomass (g DM $\mathrm{m}^{-2}$ ) all fell in the middle of the range of CARICOMP values; salinity was at the high end of the range; blade length, blade mass growth and blade specific mass growth were at the lower end of the range; and blade width fell below the range. CARICOMP sites were not selected to be 'typical' sites; the most pristine and bestdeveloped $T$. testudinum pastures were selected
(CARICOMP 1997b). From a thorough review of the literature, Duarte \& Chiscano (1999) reported a median value of aboveground specific mass growth of $2 \% \mathrm{~d}^{-1}$ for ungrazed T. testudinum; our unclipped plots had a mean of $1.6 \% \mathrm{~d}^{-1}\left(\mathrm{SD}=0.4 \% \mathrm{~d}^{-1}\right)$.

\section{Effects of clipping}

Prior to initiation of clipping, there was no significant difference between clipped and unclipped plots for any structural parameters (Table 2). Clipping had significant effects on several structural parameters (repeated-measures ANOVA, Table 1, Fig. 2). Of course, blade length and blade biomass were significantly lower in clipped plots because of the clipping treatment, so those data are not presented. Annual mean blade length and biomass in the 15 unclipped plots were $12.1 \mathrm{~cm}(\mathrm{SD}=1.2 \mathrm{~cm})$ and $59.8 \mathrm{~g} \mathrm{DM} \mathrm{m}^{-2}$ $\left(\mathrm{SD}=6.9 \mathrm{~g} \mathrm{DM} \mathrm{m}^{-2}\right)$, respectively. Significant treatment (clipping) effects were found for blade width, which was significantly narrower in clipped plots (Table 1, Fig. 2b), and detrital layer thickness (Table 1, Fig. 2c), which was significantly thinner in clipped plots. Blade width was the only structural parameter that had a significant time $\times$ treatment interaction (Table 1), apparently as a result of the initial rapid decline followed by a plateau beginning in November 1999. Detrital layer thickness in clipped plots exhibited a slower decline, with substantial deviation from unclipped plots occurring after $1 \mathrm{yr}$; the time $\times$ treatment interaction approached significance $(p=0.064$, Table 1$)$.

Table 2. Thalassia testudinum. The p-values of independentsample $t$-tests conducted between clipped and unclipped treatments for parameters before the start of the clipping treatment and comparison of summer-initiated and winterinitiated plots after 11 mo of clipping. Rhizomes were not collected in winter-initiated clipped plots. Sample sizes are $(\mathrm{n}=$ unclipped, clipped). Significant values are in bold

\begin{tabular}{|lccc|}
\hline & $\begin{array}{c}\text { Before } \\
\text { clipping } \\
(\mathrm{n}=15,15)\end{array}$ & $\begin{array}{c}\text { Summer- } \\
\text { initiated } \\
\text { clipping } \\
(\mathrm{n}=15,14)\end{array}$ & $\begin{array}{c}\text { Winter- } \\
\text { initiated } \\
\text { clipping } \\
(\mathrm{n}=15,5)\end{array}$ \\
\hline Blade length & 0.902 & $\mathbf{< . 0 0 1}$ & $<\mathbf{0 . 0 0 1}$ \\
Blade width & 0.593 & $\mathbf{< . 0 0 1}$ & $\mathbf{< 0 . 0 0 1}$ \\
Blades per shoot & 0.662 & 0.361 & 0.083 \\
Shoot density & 0.976 & 0.809 & 0.207 \\
Detrital layer & 0.663 & 0.729 & 0.186 \\
Blade biomass & 0.385 & $\mathbf{< 0 . 0 0 1}$ & $<\mathbf{0 . 0 0 1}$ \\
Rhizome biomass & 0.289 & - & - \\
Blade linear growth & - & $\mathbf{< 0 . 0 0 1}$ & $<\mathbf{0 . 0 0 1}$ \\
Blade area growth & - & $\mathbf{0 . 0 0 6}$ & 0.744 \\
Blade mass growth & - & $\mathbf{0 . 1 4 3}$ & 0.189 \\
Blade specific mass & - & $\mathbf{< . 0 0 1}$ & $\mathbf{< 0 . 0 0 1}$ \\
growth & & & \\
\hline
\end{tabular}


Shoot density (Fig. 2d), number of blades per shoot (Fig. 2e) and rhizome biomass (Fig. 2f) did not have significant treatment effects (Table 1), but there were non-significant trends for clipped plots to have lower shoot densities and higher numbers of blades per shoot. All structural parameters, except rhizome biomass, had significant time effects (Table 1), reflecting seasonal changes in both clipped and unclipped plots.
All growth parameters had very significant time effects (repeated-measures ANOVA, Table 1) because of the strong response of growth to temperature. Significant treatment (clipping) effects were found for linear, area and specific mass growth. Linear growth rates of blades $\left(\mathrm{mm} \mathrm{d}^{-1}\right)$ were significantly higher in clipped plots than in unclipped plots (Table 1, Fig. 3a). Because clipped blades were significantly nar-
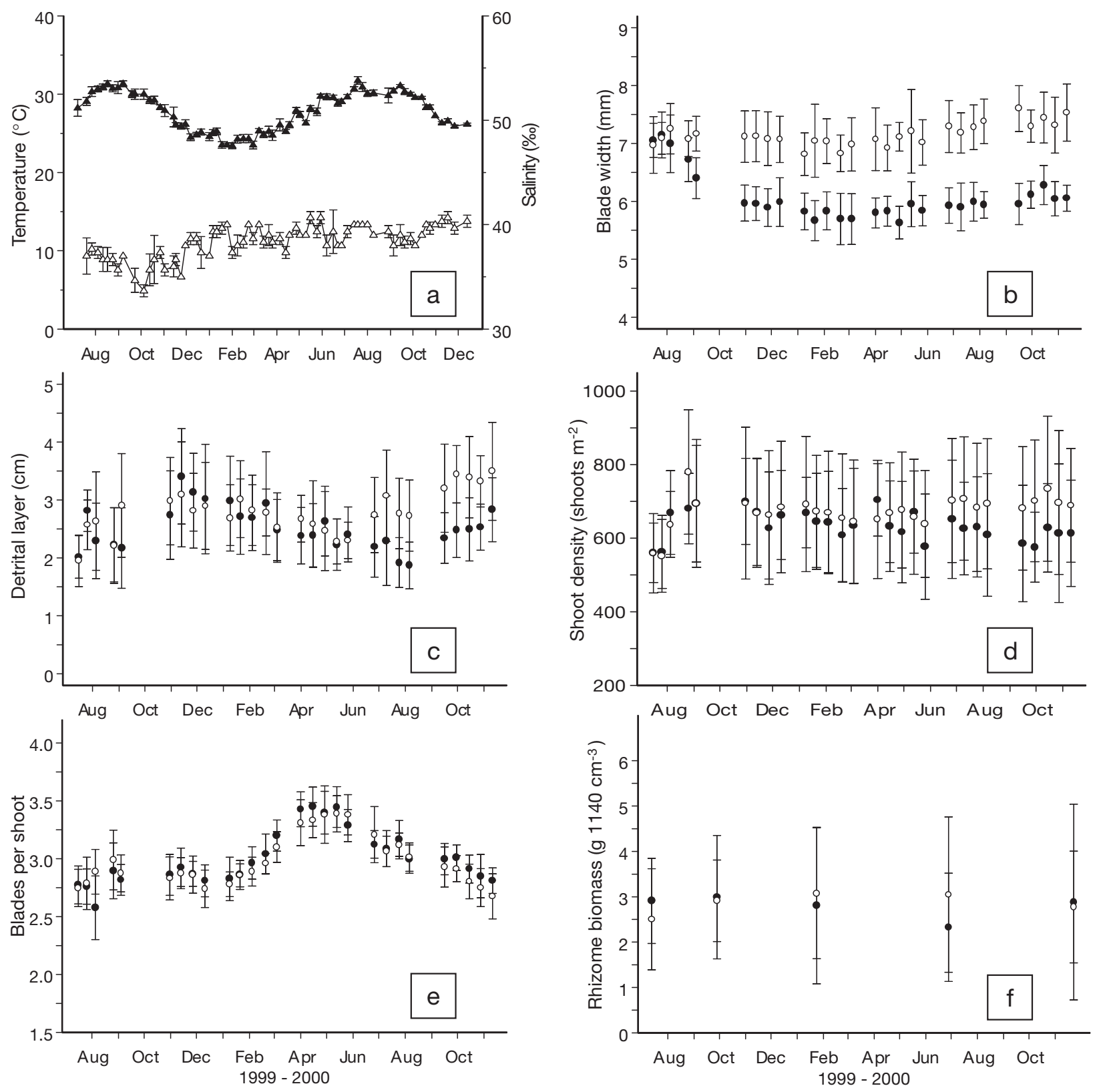

Fig. 2. (a) Mean values $( \pm 1 \mathrm{SD})$ for each week for water temperature $\left({ }^{\circ} \mathrm{C}_{i} \mathbf{\Delta}\right)$ and salinity $(\% ; \Delta)$ in the study area from July 1999 to December 2000. (b-f) Thalassia testudinum. Comparison of structural parameters (mean \pm 1SD) in clipped (•) and unclipped ( $(\circ)$ plots of seagrass. Gaps in the data reflect interruptions in sampling due to hurricanes in September 1999 and August 2000. (b) Blade width $(\mathrm{mm})$; (c) thickness of detrital layer $(\mathrm{cm})$; (d) shoot density (shoots $\mathrm{m}^{-2}$ ); (e) number of blades per shoot; and (f) rhizome biomass ( $\mathrm{g}$ DM per $1140 \mathrm{~cm}^{3}$ ). On the $x$-axis, monthly tick marks represent the first day of each month 
rower than unclipped blades (Fig. 2b), comparison of linear growth may be misleading, but growth of blade area $\left(\mathrm{mm}^{2} \mathrm{~d}^{-1}\right)$, calculated from linear growth and mean blade width, was also significantly greater in clipped plots (Table 1, Fig. 3b). Rate of blade mass growth $\left(\mathrm{g} \mathrm{m}^{-2} \mathrm{~d}^{-1}\right)$ was not significantly different between clipped and unclipped plots (Table 1, Fig. 3c), perhaps because of the trend for lower shoot density in clipped plots (Fig. 2d). The equivalent mass production in clipped and unclipped plots and the significantly lower blade biomass in clipped plots yielded significantly higher specific mass growth (blade mass growth/blade biomass) in clipped plots than in unclipped plots (Table 1, Fig. 3d). Specific mass growth had a significant time $\times$ treatment interaction (Table 1), apparently because there was an increase between the first 2 sampling periods for unclipped plots and a decrease between the equivalent pair of values for clipped plots. The pattern in the clipped plots may have resulted from overcompensatory growth (increased net primary production) in response to the first clipping. Mass growth had a marginally significant time $\times$ treatment interaction $(p=0.045$, Table 1$)$, probably resulting from the separation of values during the second summer in between convergent values for the 2 winters.

\section{Effects of season when clipping was initiated}

Whether clipping was initiated in summer (July) or winter (February) had little effect on the responses to the clipping treatment measured after 11 mo of clipping (Table 2). Conclusions regarding the significance and direction of the differences were the same for all parameters except blade area growth. The rate of blade area growth was significantly higher in clipped plots initiated in summer than in unclipped plots, whereas there was no significant treatment effect for clipped plots initiated in winter, primarily as a result of unusually great variation in the final values for winterinitiated clipped plots.
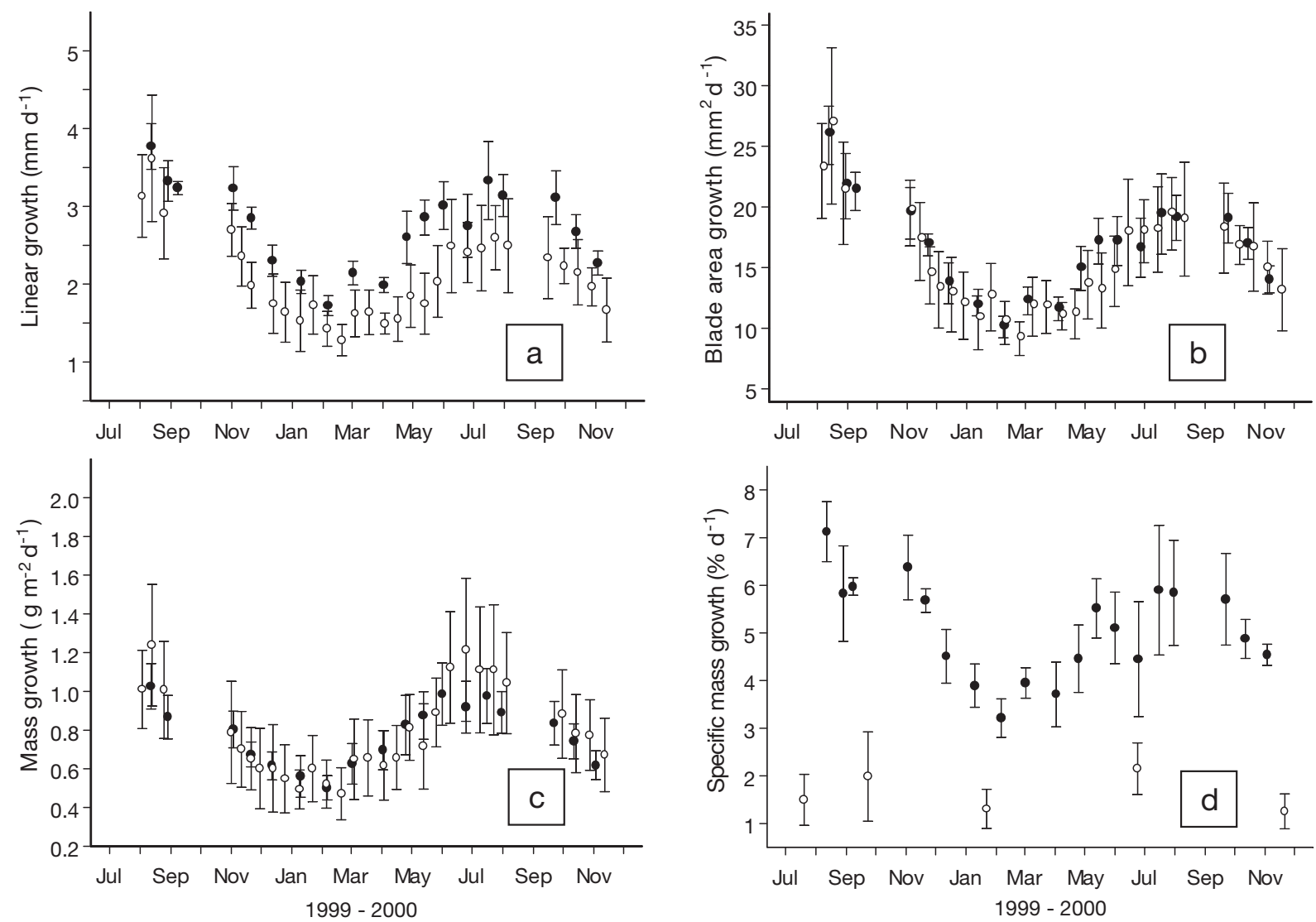

Fig. 3. Thalassia testudinum. Comparison of growth parameters (mean \pm 1 SD) in clipped $(\bullet)$ and unclipped (o) plots of seagrass. Gaps in the data reflect interruptions in sampling due to hurricanes in September 1999 and August 2000. (a) Linear blade growth $\left(\mathrm{mm} \mathrm{d}^{-1}\right)$; (b) area blade growth $\left(\mathrm{mm}^{2} \mathrm{~d}^{-1}\right)$; (c) mass blade growth ( $\left.\mathrm{g} \mathrm{DM} \mathrm{m} \mathrm{d}^{-1}\right)$; and (d) specific mass blade growth $\left(\% \mathrm{~d}^{-1}\right)$. On the $x$-axis, monthly tick marks represent the first day of each month 
The long duration of the experiment may have been responsible for the lack of importance of the season when clipping was initiated. Effects of sea urchin grazing on Thalassia testudinum productivity in the Florida Keys were significantly different when clipping was initiated in spring or summer (Valentine et al. 2000). Heck \& Valentine (1995) predicted that season of initiation would be a significant factor in the effect of sea urchin grazing in the northeastern Gulf of Mexico. Both of these studies were based on shorter trials (3 to $4 \mathrm{mo}$ ) and in areas with greater temperature fluctuations than our study (Heck \& Valentine 1995, Valentine et al. 2000).

\section{DISCUSSION}

\section{Simulation of green turtle grazing}

Grazing plots can be maintained by green turtles for at least a year (Bjorndal 1980) and range in area from 10 to $100 \mathrm{~m}^{2}$ or larger (Ogden et al. 1983, Williams 1988). Grazing turtles position themselves on or just above the substrate and graze every blade of seagrass in an area (Fig. 1, J. Ogden pers. comm.) to within a few centimeters of the substrate, biting off segments of seagrass about $5 \mathrm{~cm}$ long (Bjorndal 1980, Williams 1988). Primary foraging times are during the morning and afternoon. Green turtles rest during the night and often during the middle of the day in hard bottom areas that may be up to $0.5 \mathrm{~km}$ from their grazing plots (Bjorndal 1980, Ogden et al. 1983).

Our clipping protocol simulated green turtle grazing as closely as possible at appropriate spatial and temporal scales with re-clipping intervals that incorporated seasonal growth rates and mimicked natural grazing rates. The $9 \mathrm{~m}^{2}$ plot size represented a realistic size, while allowing sufficient replication for robust statistical analysis. Isolation of clipped plots by severing rhizomes simulated a larger grazed area. Thalassia testudinum blades were clipped to the appropriate height and during the times of day when green turtles usually forage. Plots were re-clipped when mean blade length in the plots reached the bite size of a turtle. Each time a plot was clipped, all blades were removed from the area, as if ingested by a turtle. Clipping was conducted by hovering just above the plots to mimic the level of disruption to the community caused by grazing turtles.

Nutrient input from green turtle urine and feces was not simulated in the clipped plots, but is not a serious concern because turtle feces may not be deposited in grazed plots, and turtle urine may not make a substantial contribution to nitrogen budgets in the grazed plots (Thayer et al. 1984). Turtles often defecate when they first become active at their resting areas before moving to the grazing plots (Bjorndal 1980). Also, gases produced by the hindgut fermentation in green turtles (Bjorndal 1979) are trapped in the feces and cause them to float away from the grazing area (Balazs et al. 1993). Seagrasses absorb most of their nitrogen from sediment pools through roots and rhizomes, not directly from the water column through the blades (Lee \& Dunton 1999).

More importantly, because nutrient addition by green turtles was not simulated, our values of Thalassia testudinum growth rates and nutrient quality in clipped plots may be lower than in natural green turtle grazing areas. If so, these lower values would overestimate any negative effects of grazing on T. testudinum nutrient composition and productivity and underestimate sustainability of the grazing regime. Therefore, our conclusions that productivity was not affected and that the grazing regime is sustainable over at least a 16 mo period are strengthened.

Our conclusions on the responses of Thalassia testudinum to clipping differ from those of some previous studies, as discussed below. These differences may result from the smaller size of clipped areas (e.g. $10 \times$ $10 \mathrm{~cm}$, or $1 \mathrm{~m}^{2}$ ), shorter durations of the experiments, lack of rhizome severing, and/or pre-determined time intervals between clippings employed in earlier studies. Small plot areas have different shading and hydrodynamic effects than larger plots. Studies that measure effects of a single clipping or of grazing over a few days, weeks, or months would not reveal long-term effects of grazers that forage in the same areas for a year or longer. Intact rhizomes can transfer nutrients from rhizomes below undisturbed shoots to rhizomes below clipped shoots, elevating productivity above what it would have been if rhizomes had been severed (Libes \& Boudouresque 1987). Pre-determined clipping intervals may not allow re-growth of seagrass blades that would occur in naturally grazed plots, where grazing organisms adjust their grazing rates in response to changes in vegetation growth. Because clipping intervals in our study were determined by $5 \mathrm{~cm}$ re-growth of the blades, similar to the grazing behavior of green turtles, photosynthetic material regrew, which may have restored, or at least lowered mobilization of, rhizome nutrient stores.

\section{Effects of grazing on structure and productivity in Thalassia testudinum pastures}

The structural complexity of Thalassia testudinum pastures is greatly reduced in grazing plots (Fig. 1). Long leaf blades are shortened to stubble, blades are narrower, shoot density may decrease and the detrital layer is reduced. Because species richness is related to the 
structural complexity of seagrass beds (Hemminga \& Duarte 2000), biodiversity may decrease in grazed areas.

A major role attributed to long, ungrazed Thalassia testudinum blades is particle entrapment, which results in increased nutrient cycling and sediment stabilization (Zieman 1982). We expected, therefore, that simulated grazing would result in significant decreases in thickness of the detrital layer. These changes would occur as currents swept detritus and smaller sediment particles out of the clipped plots and as blades were removed instead of being allowed to senesce and decompose in place. After 12 mo of clipping, depth of the detrital layer did decrease in clipped plots relative to unclipped plots and remained thinner for the duration of the trial. The low current flow at our study site may have contributed to the slow response in detrital thickness in the clipped plots. Low water movement may have allowed the detritus layer present at the beginning of our experiment to remain and decompose in situ. The delayed (after 12 mo) decline in the thickness of the detritus layer in clipped plots suggests that thinning of the detritus layer was a result of decomposition and lack of input, as we continued to remove all blade biomass.

Simulated green turtle grazing conducted over a 16 mo period resulted in rates of blade mass growth (g DM m ${ }^{-2} \mathrm{~d}^{-1}$ ) not significantly different in clipped and unclipped plots, and in significantly increased rates of specific blade mass growth $\left(\% \mathrm{~d}^{-1}\right)$ in clipped plots. A trend for a higher number of blades per shoot in clipped plots offset the trend for lower shoot density (shoots $\mathrm{m}^{-2}$ ) toward the end of the clipping trial, and maintained productivity.

The extent to which herbivory can stimulate increased rates of production in plants, through either compensatory growth in which net primary production (NPP) is maintained, or overcompensatory growth (increased NPP), varies among systems (Belsky et al. 1993, Milchunas \& Lauenroth 1993, Leriche et al. 2003). In our study, Thalassia testudinum exhibited compensatory growth in response to clipping based on production of blade dry mass. The only evidence of overcompensatory growth is the high initial specific mass growth value in clipped plots (Fig. 3d), which apparently resulted in the significant time $\times$ treatment interaction.

Responses of Thalassia testudinum to grazing depend on many parameters, including proportion of leaf removal (Cebrián et al. 1998), season, duration of grazing and grazing behavior of herbivores. Studies have yielded contradictory results, and, because many are based on short-term trials in small areas, caution is warranted in extrapolations to larger scales. Some studies report that grazing increases productivity in T. testudinum. Aboveground primary production in- creased in response to grazing by the sea urchin Lytechinus variegatus in the northeastern Gulf of Mexico and during the summer in the Florida Keys (Valentine et al. 1997, 2000). The former increase in productivity was a result of a significant increase in shoot density in response to grazing, which is opposite to both the trend in our study for a decrease in shoot density and the significant decrease in shoot density in T. testudinum grazed by L. variegatus during winter in Biscayne Bay, Florida (Maciá 2000). Parrotfish grazing on T. testudinum in the northern Florida Keys did not significantly decrease standing biomass, although parrotfish consumed substantial quantities of seagrass blades (Kirsch et al. 2002). Kirsch et al. (2002) concluded that this lack of response resulted because either herbivory stimulated higher rates of primary productivity or periods of intense grazing were followed by periods of less intense grazing, which allowed the grazed plants to replace the removed biomass.

In contrast, other studies have found that grazing decreases aboveground productivity in Thalassia testudinum. The sea urchin Lytechinus variegatus can decrease productivity in $T$. testudinum or eliminate patches, depending on the season and density of sea urchins (Heck \& Valentine 1995). Aboveground productivity of $T$. testudinum decreased in areas off St. Croix that had been grazed by sea urchins and green turtles (Zieman et al. 1984). In a T. testudinum meadow in St. John, USVI, disturbed by a high density of anchor scars and intense grazing by green turtles, productivity in grazed areas was low (Williams 1988). After green turtles were prevented from grazing in $4 \times 4 \mathrm{~m}$ exclusion cages for $3 \mathrm{mo}$, productivity increased inside the cages (Williams 1988).

Grazing increases specific mass growth in Thalassia testudinum, although prolonged intense grazing can apparently reduce specific mass growth to below that of ungrazed areas. The mean specific mass growth of clipped T. testudinum in our study was $5.1 \% \mathrm{~d}^{-1}$ (SD = $1.0 \% \mathrm{~d}^{-1}$ ), whereas that for unclipped $T$. testudinum was only $1.6 \% \mathrm{~d}^{-1}\left(\mathrm{SD}=0.4 \% \mathrm{~d}^{-1}\right)$. In $T$. testudinum areas grazed by green turtles for more than a few weeks at St. Croix, specific mass growth was $\sim 6 \% \mathrm{~d}^{-1}$, and adjacent ungrazed areas exhibited specific mass growth of $\sim 3 \% \mathrm{~d}^{-1}$ (Zieman et al. 1984). We calculated that the specific mass growth of blades in the highly disturbed T. testudinum pasture heavily grazed by green turtles in St. John, USVI, was between 0.7 and $3.2 \% \mathrm{~d}^{-1}$, based on values presented in Williams (1988).

\section{Sustainability of grazing by green turtles}

Green turtles are not the only marine herbivores to practice cultivation grazing. Dugongs (Preen 1995), 
manatees (Lefebvre et al. 2000), and a variety of fishes, limpets and polychaetes (Branch et al. 1992) feed in areas that they have altered by previous grazing. In addition to giving access to young, rapidly growing plant tissue, as in the grazing plots of green turtles, grazing activities of these other species often result in altered species composition.

There is little information on how long cultivated plots can be sustained by any of these species. Grazing plots can be maintained by green turtles for at least a year (Bjorndal 1980, Ogden et al. 1983), but the duration over which compensatory growth in blade mass can be maintained is not known. Intensive grazing, in which most of the aboveground biomass is removed, should eventually cause a decline in Thalassia testudinum productivity as a result of reduced photosynthetic area, depleted nutrient reserves in sediment porewater and rhizomes and decreased detritus input (Zieman et al. 1984, Williams 1988, Heck \& Valentine 1995). Loss of nitrogen input from detritus may be offset if nitrogen fixation increases in response to nitrogen limitation (Thayer et al. 1984), which would lengthen the time a grazing plot can be sustained. Decreased blade productivity and nutrient quality should lead to abandonment of the plot (Thayer et al. 1984, Zieman et al. 1984). Changes in abundance of green turtles on a foraging ground in the southern Bahamas have been related to changes in productivity of $T$. testudinum as a result of overgrazing at high green turtle densities (Bjorndal et al. 2000, 2005).

We maintained clipped plots for 16 mo to simulate long-term grazing conditions, but, although our clipping trial greatly exceeded the duration of all previous studies, it was not long enough to document the expected decline in blade productivity. There was a trend for lower rates of mass growth in clipped plots in the second summer of our study, but, by autumn, that trend had disappeared (Fig. 3c). At the end of the 16 mo period, blade mass growth and rhizome biomass had not declined relative to unclipped plots, and blade nitrogen and phosphorus remained elevated (K. L. Moran \& K. A. Bjorndal unpubl. data). However, there were indications that the simulated grazing regime could not be sustained indefinitely. Early in the clipping trial, blade width narrowed in the clipped plots, a well-recognized indication of stress (Williams 1988). By 11 mo after the initiation of clipping, organic matter content and nitrogen content (as \% of dry matter) of rhizomes began to decline (K. L. Moran \& K. A. Bjorndal unpubl. data), followed by a significant thinning of the detrital layer and a non-significant decline in shoot density after a year of clipping. We did not simulate return of nutrients to our clipped plots in the form of feces or urine from green turtles; such nutrient inputs should increase the duration of sustained nutrient quality and productivity in grazed plots.

That Thalassia testudinum can maintain productivity under sustained grazing is not surprising given its long evolutionary history of intense grazing (Domning 2001). Under the conceptual framework developed by Meijden et al. (1988) and further elaborated by Belsky et al. (1993), T. testudinum would be classified as a plant resistant to damage (e.g. herbivory) that employs both evolutionary strategies of tolerance and, perhaps, avoidance. T. testudinum has characteristics of damage-tolerant plants that rely on rapid regrowth (Belsky et al. 1993): belowground storage organs, ability to transport nutrients from undamaged to damaged parts of the plant, basal meristems protected from damage and sustained compensatory growth after grazing. Higher levels of condensed tannins in clipped blades (Moran \& Bjorndal unpubl. data), indicating induction of secondary compounds in response to tissue damage, are a defensive response of damage-avoiding plants.

\section{Estimates of carrying capacity of Thalassia testudinum pastures}

A wide range of carrying capacities $(K)$ for green turtles in the Caribbean has been calculated based on 3 estimates of intake within a relatively narrow range, 2 very different estimates of Thalassia testudinum productivity in grazed areas and an estimate of the coverage of $T$. testudinum in the Caribbean (Table 3; Bjorndal et al. 2000). We can now calculate $K$ based on the estimate of sustained productivity of $T$. testudinum pastures under prolonged simulated grazing from our study. Mean productivity of clipped $T$. testudinum during the last 12 mo of our study (to account for seasonal effect) was $0.76 \mathrm{~g} \mathrm{DM} \mathrm{m}^{-2} \mathrm{~d}^{-1}(\mathrm{SD}=0.16, \mathrm{n}=14$ summer-initiated clipped plots), or $2774 \mathrm{~kg} \mathrm{DM} \mathrm{ha}{ }^{-1} \mathrm{yr}^{-1}$, which falls between the 2 productivity values used by Bjorndal et al. (2000). Estimates of $K$ based on this productivity value fall in the upper range of those presented by Bjorndal et al. (2000) (Table 3). For calculations of $K$ based on numbers of turtles, $50 \mathrm{~kg}$ is used as an estimate of mean size of green turtles under a stable age distribution; a $50 \mathrm{~kg}$ green turtle is many years from reaching sexual maturity (Bjorndal et al. 2000). These $K$ values are based on very rough estimates of available seagrass for foraging turtles in the Caribbean. Also, these estimates do not include other food resources used by green turtles in the Caribbean, such as algae and invertebrates (Bjorndal 1997), which may well be ingested to a greater extent if availability of seagrasses declines. In addition, the consumption of $T$. testudinum by other Caribbean herbivores is not included. These last 2 omissions will tend to offset each other. 
Table 3. Chelonia mydas. Carrying capacities for green turtles on Thalassia testudinum pastures in the Caribbean. Calculations are based on 3 levels of intake ( $\mathrm{kg}$ DM Thalassia $\mathrm{kg}^{-1}$ green turtle $\mathrm{yr}^{-1}$ ) estimated by 3 different methods and on 3 levels of T. testudinum productivity (DM = dry mass). Modified from Bjorndal et al. (2000)

\begin{tabular}{|c|c|c|c|c|c|c|}
\hline \multirow{2}{*}{$\begin{array}{l}\text { T. testudinum } \\
\text { productivity } \\
\left(\mathrm{kg} \mathrm{DM} \mathrm{ha}^{-1} \mathrm{yr}^{-1}\right)\end{array}$} & \multicolumn{2}{|c|}{ Intake $0.74^{\mathrm{a}}$} & \multicolumn{2}{|c|}{ Intake $1.17^{\mathrm{b}}$} & \multicolumn{2}{|c|}{ Intake $1.77^{\mathrm{c}}$} \\
\hline & $\mathrm{kg}$ turtle ha $\mathrm{h}^{-1}$ & $\begin{array}{c}\text { No. of } \\
\text { turtles in } \\
\text { Caribbean }^{\mathrm{d}}\end{array}$ & $\mathrm{kg}$ turtle ha ${ }^{-1}$ & $\begin{array}{c}\text { No. of } \\
\text { turtles in } \\
\text { Caribbean }^{\mathrm{d}}\end{array}$ & $\mathrm{kg}$ turtle ha ${ }^{-1}$ & $\begin{array}{c}\text { No. of } \\
\text { turtles in } \\
\text { Caribbean }^{\mathrm{d}}\end{array}$ \\
\hline Heavy grazing ${ }^{\mathrm{e}}$ & 292 & 38544000 & 185 & 24420000 & 122 & 16104000 \\
\hline Present study ${ }^{\mathrm{f}}$ & 3748 & 494736000 & 2371 & 312972000 & 1567 & 206844000 \\
\hline Moderate grazing ${ }^{g}$ & 4439 & 585948000 & 2808 & 370656000 & 1856 & 244992000 \\
\hline \multicolumn{7}{|c|}{ a Bjorndal (1982); based on calculation of energy budget for adult female } \\
\hline \multicolumn{7}{|c|}{${ }^{\mathrm{b}}$ Bjorndal (1980); based on indigestible lignin ratio and daily feces production } \\
\hline \multicolumn{7}{|c|}{${ }^{\mathrm{c}}$ Williams (1988); based on estimates of daily bite counts and bite size } \\
\hline \multirow{2}{*}{\multicolumn{7}{|c|}{ d Based on 6600000 ha T. testudinum in the Caribbean (Jackson 1997) and a turtle size of $50 \mathrm{~kg}$}} \\
\hline & & & & & & \\
\hline \multicolumn{7}{|c|}{$216 \mathrm{~kg} \mathrm{DM} \mathrm{ha}{ }^{-1} \mathrm{yr}^{-1}(\mathrm{re}-$ calculated from Williams 1988, her Table 4) } \\
\hline \multicolumn{7}{|c|}{ g $3285 \mathrm{~kg} \mathrm{DM} \mathrm{ha}^{-1} \mathrm{yr}^{-1}$ (Zieman et al. 1984) } \\
\hline
\end{tabular}

Green turtles are endangered worldwide (HiltonTaylor 2000), and management efforts to restore populations of green turtles need recovery goals that are biologically meaningful. The Marine Turtle Specialist Group of the World Conservation Union (IUCN) adopted the goal of rebuilding sea turtle populations to the level at which they fulfill their ecological roles (MTSG 1995). At present, we cannot assign a specific abundance at which the green turtle, or any species of sea turtle, fulfills its ecological role; research directed at quantifying the roles of sea turtles in ecosystems is needed (Bjorndal \& Bolten 2003). The $K$-value for green turtles in the Caribbean can serve as the maximum population level at which green turtles fulfill their ecological roles. The minimum level at which ecological functions are performed is almost certainly lower.

Calculations of $K$ also provide maximum estimates of green turtle population levels before exploitation by humans began (Jackson et al. 2001), for reconstruction models of past marine ecosystems. This estimate assumes that pre-exploitation green turtle populations were limited by food supplies, as suggested by Randall (1965), which is not unreasonable, because populations of large herbivores are often regulated by food limitation (Sinclair 1995). Because of the loss of seagrass habitats (Short \& Wyllie-Echeverria 1996, Duarte 2002, Green \& Short 2003), the populations of green turtles that existed before humans arrived in the Caribbean could probably not be supported today. However, the estimates of pre-human sea turtle population levels are essential to provide the proper perspective for evaluating the ecological roles of sea turtles. Because the declines in green turtle populations were so massive and occurred so long ago (Parsons 1962, Jackson et al. 2001, Pandolfi et al. 2003), it is difficult to assess the extent to which modern Thalassia testudinum pastures have been altered since the time when grazing by green turtles dominated nutrient cycling. This information is essential for efforts to reconstruct and restore marine ecosystems (Pitcher 2001).

\section{CONCLUSIONS}

Simulated grazing significantly affected the physical structure and productivity of Thalassia testudinum plots. Some of the suite of responses of T. testudinum to intensive grazing by green turtles proposed by Thayer et al. (1984) were confirmed by our study and others were not. Repeated re-cropping resulted in narrower blade width and thinner detrital layer. Also, there was a non-significant trend for the number of shoots per square meter to decline. However, in contrast to the proposed responses, blade mass growth did not exhibit an initial increase, and, rather than decreasing, the number of blades per shoot showed a non-significant trend to increase. Most importantly, blade production had not declined after 16 mo of clipping.

The maintenance of elevated nutrient composition in blades (K. L. Moran \& K. A. Bjorndal unpubl. data) and consistent blade productivity indicates that recropping of Thalassia testudinum plots is sustainable for long periods, substantially longer than previously proposed. More research is needed to evaluate effects of green turtle grazing on seagrass ecosystems under different environmental conditions. Long-term grazing trials in areas with greater current flow and less seasonal temperature fluctuation would be particularly valuable. 
Acknowledgements. We are grateful to A. Bolten, whose insights and discussions improved the quality of the study and whose assistance with logistics made this study possible. C. Chapman, L. Chapman, T. Frazer and J. Ogden offered advice and support at many stages of this study. L. ConwayCranos, J. Greenawalt, J. Hale, S. Schopmeyer, C. WardPaige, D. Winchester and D. Wood were invaluable in data collection. We thank S. Aptekar for use of his grazing plot image, A. Arenas for obtaining the image and S. White for image preparation. This paper benefited from the participation of K.A.B. in the Long-Term Ecological Records of Marine Communities Working Group supported by the National Center for Ecological Analysis and Synthesis (funded by U.S. National Science Foundation Grant DEB-0072909, the University of California, and the University of California, Santa Barbara). The staff of the Caribbean Marine Research Center supplied logistical support and access to the field site. Financial support was provided by N. Thompson and the National Marine Fisheries Service, Southeast Fisheries Science Center; J. Marr, N. Langley and the Caribbean Marine Research Center; Disney Wildlife Conservation Fund; National Fish and Wildlife Foundation; the Archie Carr Center for Sea Turtle Research; and grants to K.L.M. from the PADI Foundation, Sigma Xi and the American Museum of Natural History.

\section{LITERATURE CITED}

Aragones L, Marsh H (2000) Impact of dugong grazing and turtle cropping on tropical seagrass communities. Pac Conserv Biol 5:277-288

Audubon MR (1897) Audubon and his journals, Vol 2. Books for Libraries Press, Freeport, NY

Balazs GH (1999) Factors to consider in the tagging of sea turtles. In: Eckert KL, Bjorndal KA, Abreu-Grobois FA, Donnelly M (eds) Research and management techniques for the conservation of sea turtles. IUCN/SSC Marine Turtle Specialist Group, Washington, DC, p 101-109

Balazs GH, Fujioka R, Fujioka C (1993) Marine turtle faeces on Hawaiian beaches. Mar Pollut Bull 26:392-394

Belsky AJ, Carson WP, Jensen CL, Fox GA (1993) Overcompensation by plants: herbivore optimization or red herring? Evol Ecol 7:109-121

Bjorndal KA (1979) Cellulose digestion and volatile fatty acid production in the green turtle, Chelonia mydas. Comp Biochem Physiol 63A:127-133

Bjorndal KA (1980) Nutrition and grazing behavior of the green turtle, Chelonia mydas. Mar Biol 56:147-154

Bjorndal KA (1982) The consequences of herbivory for the life history pattern of the Caribbean green turtle. In: Bjorndal KA (ed) Biology and conservation of sea turtles. Smithsonian Institution Press, Washington, DC, p 111-116

Bjorndal KA (1997) Foraging ecology and nutrition of sea turtles. In: Lutz PL, Musick JA (eds) The biology of sea turtles. CRC Press, Boca Raton, FL, p 199-231

Bjorndal KA, Bolten AB (2003) From ghosts to key species: restoring sea turtle populations to fulfill their ecological roles. Mar Turtle Newsl 100:16-21

Bjorndal KA, Jackson JBC (2003) Roles of sea turtles in marine ecosystems: reconstructing the past. In: Lutz PL, Musick JA, Wyneken J (eds) Biology of sea turtles, Vol II. CRC Press, Boca Raton, FL, p 259-273

Bjorndal KA, Bolten AB, Chaloupka MY (2000) Green turtle somatic growth model: evidence for density dependence. Ecol Appl 10:269-282

Bjorndal KA, Bolten AB, Chaloupka MY (2005) Evaluating trends in abundance of immature green turtles, Chelo- nia mydas, in the Greater Caribbean. Ecol Appl 15: 304-314

Branch GM, Harris JM, Parkins C, Bustamante RH, Eekhout S (1992) Algal 'gardening' by grazers: a comparison of the ecological effects of territorial fish and limpets. In: John DM, Hawkins SJ, Price JH (eds) Plant-animal interactions in the marine benthos. Clarendon Press, Oxford, p 405-423

CARICOMP (Caribbean Coastal Marine Productivity Programme) (1997a) Meteorological and oceanographic characterization of coral reef, seagrass and mangrove habitats in the Wider Caribbean. In: Lessios HA, MacIntyre IG (eds) Proc 8th Int Coral Reef Symp, Vol 1. Smithsonian Tropical Research Institute, Balboa, p 657-662

CARICOMP (Caribbean Coastal Marine Productivity Programme) (1997b) Variation in ecological parameters of Thalassia testudinum across the CARICOMP network. In: Lessios HA, MacIntyre IG (eds) Proc 8th Int Coral Reef Symp, Vol 1. Smithsonian Tropical Research Institute, Balboa, p 663-668

Cebrián J, Duarte CM (1998) Patterns in leaf herbivory on seagrasses. Aquat Bot 60:67-82

Cebrián J, Duarte CM, Agawin NSR, Merion M (1998) Leaf growth response to simulated herbivory: a comparison among seagrass species. J Exp Mar Biol Ecol 220:67-81

den Hartog C (1970) The seagrasses of the world. North Holland, Amsterdam

Domning DP (2001) Sirenians, seagrasses, and Cenozoic ecological change in the Caribbean. Palaeogeogr Palaeoclimatol Palaeoecol 166:27-50

Duarte CM (2002) The future of seagrass meadows. Environ Conserv 29:192-206

Duarte CM, Chiscano CL (1999) Seagrass biomass and production: a reassessment. Aquat Bot 65:159-174

Green EP, Short FT (eds) (2003) World atlas of seagrasses. University of California Press, Berkeley, CA

Hay ME (1984) Patterns of fish and urchin grazing on Caribbean coral reefs: Are previous results typical? Ecology 65:446-454

Heck KL Jr, Valentine JF (1995) Sea urchin herbivory: evidence for long-lasting effects in subtropical seagrass meadows. J Exp Mar Biol Ecol 189:205-217

Hemminga MA, Duarte CM (2000) Seagrass ecology. Cambridge University Press, Cambridge

Hilton-Taylor C (2000) IUCN Red List of threatened species. International Union for the Conservation of Nature, Gland

Jackson JBC (1997) Reefs before Columbus. Coral Reefs 16(Suppl):23-33

Jackson JBC, Kirby MX, Berger WH, Bjorndal KA and 15 others (2001) Historical overfishing and the recent collapse of coastal ecosystems. Science 293:629-638

Kikuchi T (1980) Faunal relationships in temperate seagrass beds. In: Phillips RC, McRoy CP (eds) Handbook of seagrass biology. Garland Press, New York, p 153-172

Kirsch KD, Valentine JF, Heck KL Jr (2002) Parrotfish grazing on turtlegrass Thalassia testudinum: evidence for the importance of seagrass consumption in food web dynamics of the Florida Keys National Marine Sanctuary. Mar Ecol Prog Ser 227:71-85

Lee KS, Dunton KH (1999) Inorganic nitrogen acquisition in the seagrass Thalassia testudinum: development of a whole-plant nitrogen budget. Limnol Oceanogr 44: $1204-1215$

Lefebvre LW, Reid JP, Kenworthy WJ, Powell JA (2000) Characterizing manatee habitat use and seagrass grazing in Florida and Puerto Rico: implications for conservation and management. Pac Conserv Biol 5:289-298 
Leriche H, Le Roux X, Desnoyers F, Benest D, Simioni G, Abbadie L (2003) Grass response to clipping in an African savanna: testing the grazing optimization hypothesis. Ecol Appl 13:1346-1354

Libes M, Boudouresque CF (1987) Uptake and long-distance transport of carbon in the marine phanerogam Posidonia oceanica. Mar Ecol Prog Ser 38:177-186

Maciá S (2000) The effects of sea urchin grazing and drift algal blooms on a subtropical seagrass bed community. J Exp Mar Biol Ecol 246:53-67

McRoy CP, Helfferich C (1980) Applied aspects of seagrasses. In: Phillips RC, McRoy CP (eds) Handbook of seagrass biology. Garland Publishing, New York, p 297-343

Meijden E van der, Wijn M, Verkaar HJ (1988) Defence and regrowth: alternative plant strategies in the struggle against herbivores. Oikos 51:355-363

Milchunas DG, Lauenroth WK (1993) Quantitative effects of grazing on vegetation and soils over a global range of environments. Ecol Monogr 63:327-366

Moran KL (2003) Simulated green turtle grazing: effects on structure and productivity of seagrass (Thalassia testudinum) in the central Bahamas. PhD dissertation, University of Florida, Gainesville, FL

MTSG (Marine Turtle Specialist Group) (1995) A global strategy for the conservation of marine turtles. IUCN Publications, Gland

Ogden JC (1980) Faunal relationships in Caribbean seagrass beds. In: Phillips RC, McRoy CP (eds) Handbook of seagrass biology. Garland Publishing, New York, p 173-198

Ogden JC, Robinson L, Whitlock K, Daganhardt H, Cebula R (1983) Diel foraging patterns in juvenile green turtles (Chelonia mydas L.) in St. Croix, US Virgin Islands. J Exp Mar Biol Ecol 66:199-205

Pandolfi JM, Bradbury RH, Sala E, Hughes TP and 8 others (2003) Global trajectories of the long-term decline of coral reef ecosystems. Science 301:955-958

Parsons JJ (1962) The green turtle and man. University of Florida Press, Gainesville, FL

Perneger TV (1998) What is wrong with Bonferroni adjustments? Br Med J 16:2529-2542

Pitcher TJ (2001) Fisheries managed to rebuild ecosystems? Reconstructing the past to salvage the future. Ecol Appl 11:601-617

Editorial responsibility: Otto Kinne (Editor-in-Chief), Oldendorf/Luhe, Germany
Preen A (1995) Impacts of dugong foraging on seagrass habitats: observational and experimental evidence for cultivation grazing. Mar Ecol Prog Ser 124:201-213

Randall JE (1965) Grazing effect on sea grasses by herbivorous reef fishes in the West Indies. Ecology 46:255-260

Short FT, Wyllie-Echeverria S (1996) Natural and humaninduced disturbance of seagrasses. Environ Conserv 23: $17-27$

Sinclair ARE (1995) Serengeti past and present. In: Sinclair ARE, Arcese P (eds) Serengeti II: dynamics, management, and conservation of an ecosystem. University of Chicago Press, Chicago, IL, p 3-30

Thayer GW, Engel DW, Bjorndal KA (1982) Evidence of shortcircuiting of the detritus cycle of seagrass beds by the green turtle, Chelonia mydas L. J Exp Mar Biol Ecol 62: 173-183

Thayer GW, Bjorndal KA, Ogden JC, Williams SL, Zieman JC (1984) Role of larger herbivores in seagrass communities. Estuaries 7:351-376

Valentine JF, Heck KL Jr (1999) Seagrass herbivory: evidence for the continued grazing of marine grasses. Mar Ecol Prog Ser 176:291-302

Valentine JF, Heck KL Jr, Busby J, Webb D (1997) Experimental evidence that herbivory increases shoot density and productivity in a subtropical turtlegrass (Thalassia testudinum) meadow. Oecologia 112:193-200

Valentine JF, Heck KL Jr, Kirsch KD, Webb D (2000) Role of sea urchin Lytechinus variegatus grazing in regulating subtropical turtlegrass Thalassia testudinum meadows in the Florida Keys (USA). Mar Ecol Prog Ser 200: 213-228

Williams SL (1988) Thalassia testudinum productivity and grazing by green turtles in a highly disturbed seagrass bed. Mar Biol 98:447-455

Zieman JC (1974) Methods for the study of the growth and production of turtle grass, Thalassia testudinum König. Aquaculture 4:139-143

Zieman JC (1982) The ecology of the seagrasses of South Florida: a community profile. FWS/OBS-82/25. US Fish and Wildlife Service, Washington, DC

Zieman JC, Iverson RL, Ogden JC (1984) Herbivory effects on Thalassia testudinum leaf growth and nitrogen content. Mar Ecol Prog Ser 15:151-158

Submitted:December 3, 2004; Accepted:June 30, 2005

Proofs received from author(s): November 20, 2005 